\title{
OPTIMIZATION OF POLYSACCHARIDE-RICH FRACTIONATION FROM Morinda citrifolia L. FRUIT BASED ON IMMUNOSTIMULATORY EFFECT IN VITRO
}

\author{
Ediati Sasmito*, Triana Hertiani, Senda Kartika, Faradhyta Maharani Putri, \\ Vania Setiawan, Longina Narastika
}

Faculty of Pharmacy, Universitas Gadjah Mada, Yogyakarta 55281, Indonesia

Submitted: 28-05-2014 Revised: 15-03-2015 Accepted: $30-03-2015$

*Corresponding author Ediati Sasmito

Email: ediatisasmito@yahoo.com

\begin{abstract}
Morinda citrifolia L. fruits are rich in polysaccharides of which are non toxic and possess hospes-mediated-antitumor potential. In Indonesia, noni fruit has been used empirically to enhance immune system. Previous research revealed that noni polysaccharide-rich fraction showed macrophage activity enhancement. This research aimed to optimize the method of nonipolysaccharides-rich fractionation using four different methods for polysaccharide isolation (method I, II, III, IV) and to evaluate the immunostimulatory effects of the isolated polysaccharides on macrophages and lymphocytes activities. Immunostimulatory effects were examined on male Balb/c mice in vitro. The polysaccharides were evaluated by phenol sulfuric acid test. Qualitative methods were used to detect the phytochemical characteristic. Total phenolic content was determined by using Folin-Ciocalteau method. The study showed different methods resulted in different yields, phytochemical characteristics and immunostimulatory activities of polysaccharides-rich fraction. The phytochemical test from method I, III and IVb revealed the presence of alkaloid. Method II resulted fractions with the presence of saponin. There were no protein and phenolic substances detected from all methods. The highest result of polysaccharide content was found in method IVb (32.58\%). Method III showed the highest activity on phagocytic activity of the macrophage, while method IVb exhibited the highest stimulation on lymphocyte proliferation.
\end{abstract}

Key words: Isolation method, polysaccharide, Morinda citrifolia L. immunostimulatory effect

\section{INTRODUCTION}

"Mengkudu" or Noni (Morinda citrifolia L., Rubiaceae) fruit has been reported to contain protein, polysaccharides, scopoletin, ascorbic acid, proxeronine and proxeroninase (Sjabana and Bahalwan, 2002).

Several scientific researchs have proven that its juice can stimulate immune system and help in repairing cell damages. Wang et al. (2002) reported that the fruit extract in various concentration can inhibit the tumor necrosis factor-alpha (TNF- $\alpha$ ) production (Wang et al., 2002). "Mengkudu" juice in 10\% concentration caused thymus node enlargement in experimental animals. Thymus is an important organ which produces limphocyte $\mathrm{T}$ cells, involved in body immune function and further influences anti aging activity and anti cancer, as well as protecting our body from other degenerative diseases.

Polysaccharides potency to imboost immune system has been related to stimulation effect of T-cells formation. This group of compounds have also believed to potentiate the induction of different types of antitumor effector cells such as cytotoxic T-cells, NK cells, as well as macrophages (Guan et al., 2011; Wang et al., 2012). Research on Yu-Ping-FengPowder (YP) polysaccharides, a Chinese herbal medicine consisted of Radix astragali, Atractylodes macrocephala and Radix saposhnikoviae showed stimulation effect on phagocytic activity and Tcells proliferation in Lypo-polysaccahrides (LPS) pretreatment and on Delayed Type Hypersensitivity (DTH) haemolytic test. The polysaccharides also increased the IL-2 and 
IFN- $\gamma$ production without increasing the IL-4 production (Chen et al., 2006).

The polysaccharides from "Mengkudu fruit" is believed to also play role in the fruit's activity as immunomodulator. Considering that various chemicals consisted in the fruit, an optimization in the polysaccahrides isolation process is required. Polysaccharides are polar substances, therefore it can be easily precipitated in a present of ethanol or nonpolar solvents (Sharma et al., 2012). In this research, we have adopted four different methods in isolating the polysaccharides. Method I was performed based on the isolation procedure for $M$. citrifolia polysaccharides isolation (Nayak and Mengi, 2010), while method II was derived from isolation of immune stimulant polysaccharides from edible fungus (Yin et al., 2007). Method III was derived from isolation procedure of polysaccharide-rich fraction from $M$. citrifolia (Furusawa et al., 2003), but unlike previous methods, this method used fresh fruit as starting material. Method IV (Chen et al., 2006) was derived from fractioned polysaccharides from Yu Ping Feng Powder. These methods will be simply stated as methods I-IV in the following discussion.

\section{MATERIAL AND METHODS}

Plant materials used were unripe "Mengkudu" fruit (white yellowish color) collected from the Faculty of Pharmacy, UGM, Yogyakarta Indonesia. Taxonomie identification was performed in the Pharmaceutical Biology Department, Faculty of Pharmacy, UGM, Yogyakarta Indonesia where the voucher specimen was kept. For isolation method I, II and IV, after washing, the sliced fruits were dried in oven at $50^{\circ} \mathrm{C}$, followed by pulverization. Method III required fresh sample materials.

Macrophage and lymphocyte cells were isolated from 2 months male Balb/c mice (breed by the Centre for Integrated Research and Assay, Universitas Gadjah Mada, Indonesia).

\section{Method I}

Dried pulverized sample (50g) was macerated in methanol $(300 \mathrm{~mL})$. The residue was refluxed in distilled water $(300 \mathrm{~mL})$ from $12 \mathrm{~h}$. After filtrated, supernatant was evaporated up to $100 \mathrm{~mL}$ left and $500 \mathrm{~mL}$ acetone was added to precipitated the polysaccharides. Residue $91 \mathrm{~g}$ was diluted in distilled water $(50 \mathrm{~mL})$. Further, $25 \mathrm{~mL} 12 \% \mathrm{w} / \mathrm{v}$ trichloroacetic acid was added and filtrated to eliminate the protein. Residue was put into a flask filled in with $500 \mathrm{~mL}$ acetone to eliminate more lipophilic substances. After filtration, the residue was freeze dried.

\section{Method II}

Dried pulverized samples (200g) was refluxed in distilled water $(6 \mathrm{~L})$ at $100^{\circ} \mathrm{C}$ for $50 \mathrm{~h}$. After being filtrated, the supernatant was evaporated. Afterwards, ethanol in 1:6 proportion was added and the suspension was left for $10 \mathrm{~h}$ in $10^{\circ} \mathrm{C}$. After being filtrated, the residue was freeze dried.

\section{Method III}

Fresh unripe fruit was left to become a softer consistency. Afterwards, the fruit was cleaned and washed and put into a sterile closed jar and kept in dark places for 1-3 days to obtain fruit juice. Afterwards, the juice was filtrated and evaporated. Ethanol 95\% was added excessively to obtain soluble and non soluble fraction. Non soluble fraction was separated by centrifugation, rinsed several times with ethanol and then freeze dried.

\section{Method IV}

The air-dried, methanol-pretreated dried pulverized sample $(200 \mathrm{~g})$ were macerated in $75^{\circ} \mathrm{C}$ hot water (at the ratio of $1: 20, \mathrm{w} / \mathrm{v}$ ) for $8 \mathrm{~h}$. The extract, after filtration and concentration $(200 \mathrm{~mL})$, was fractioned by precipitation with ethanol (30\%, 60\% and 95\% insequence) for $24 \mathrm{~h}$ at room temperature. The precipitates that formed by fractionation with $60 \%$ (IVa) and $95 \%$ (IVb) ethanol were collected and then freeze dried.

\section{Quantitative analyses of polysaccharide content by Phenol-Sulphuric-Acid Method (AOAC, 1990) \\ Dextran and samples (150mg), each was} hydrolized by refluxing in distilled water $(25 \mathrm{~mL})$ and $\mathrm{HCl} 2 \mathrm{~N}(25 \mathrm{~mL})$ at $100^{\circ} \mathrm{C}$ for $1 \mathrm{~h}$. Afterwards, distilled water was added to reach 
$100 \mathrm{~mL}$ solution (stock solution). This solution in $50,60,70,80$ and $100 \mu \mathrm{L}$ (standard solution) and $400 \mu \mathrm{L}$ for samples, each was added with distilled water up to $1 \mathrm{~mL}$. Each solution was added $2 \mathrm{~mL} 5 \%$ phenol v/v, immediately followed by addition of $7 \mathrm{~mL} \mathrm{H}_{2} \mathrm{SO}_{4} 37 \mathrm{~N}$. The solution was heated in the water bath $\left(100^{\circ} \mathrm{C}\right)$ for $5 \mathrm{~min}$ and left for $10 \mathrm{~min}$. Afterwards, absorbances was performed at $\lambda \max$ (400$500 \mathrm{~m})$.

\section{Phytochemical content analyses}

Systems used for planar chromatography were Toyo paper as stationary phase with nbuthanol-acetic acid-water (4;1;5, v/v, upper phase) as mobile phase and silica gel 60 GF254 precoated plate was used as stationary phase with ethyl acetate-n-propanol-glacial acetic acid-water $(4 ; 2: 2 ; 1)$ as mobile phase. UV 254 and $366 \mathrm{~nm}$ lamps were used to detect compounds with chromophores. Spraying reagents to detect the compounds were chosen based on functional groups (Spangenberg, 2008).

Molisch Test method (Rohman and Sumantri, 2007) was used to detect monosaccharides present in the fraction. Samples (before and after being hydrolized by Hirazumi and Furusawa (1999) method) 2mL of $1 \% \mathrm{w} / \mathrm{v}$ solution in distilled water was added with Molisch reagent and then $1 \mathrm{~mL}$ concentrated $\mathrm{H}_{2} \mathrm{SO}_{4}$ was added carefully. The presence of monosaccharides will be represented by a formation of a red-purplish ring between the reagent layers.

Qualitative analyses to detect the presence of protein was done by Biuret method (Rohman and Sumantri, 2007). Positive reaction will be represented by a color change to purplish blue.

Total phenolics contents of extract and fractions were determined by the FolinCiocalteu method (Chun, et al., 2003). Samples $(200 \mu \mathrm{L}, 1 \% \mathrm{w} / \mathrm{v})$ and standard solutions (20, $30,40,50,60$ and $70 \mu \mathrm{L}$ of $1 \mathrm{mg} / \mathrm{mL}$ stock), each was oxidized with $0.4 \mathrm{~mL}$ of FolinCiocalteu reagent. After stand for $5 \mathrm{~min}$, the solutions were then neutralized by addition of $4 \mathrm{~mL}$ of $7 \% \mathrm{Na}_{2} \mathrm{CO}_{3}$ and distilled water was added to reach $10 \mathrm{~mL}$ solution. After left for $120 \mathrm{~min}$, absorbances were measured at $765 \mathrm{~nm}$.
Distilled water and Folin-Ciocalteau reagent was used as blank. Total phenolics contents were calculated as gallic acid and done in triplicate.

\section{Lymphocytes isolation and proliferation assay (Ediati et al., 2006).}

Spleen tissue was isolated aseptically from Balb/c mice. After being transferred to a $50 \mathrm{~mm}$ petri dish containing $10 \mathrm{~mL}$ of RPMI 1640 (Sigma-Aldrich, Germany), the lymphocytes suspension was centrifuged at $3.200 \mathrm{rpm} 4^{\circ} \mathrm{C}$ for $4 \mathrm{~min}$. Resulted clumps were suspended in $5 \mathrm{~mL}$ Tris ammonium chloride buffer and left in RT for $15 \mathrm{~min}$. After RPMI was added to reach $10 \mathrm{~mL}$ suspension, centrifugation was performed at $3.200 \mathrm{rpm} 4^{\circ} \mathrm{C}$ for $4 \mathrm{~min}$. Resulted clumps were separated from the supernatant, washed twice with RPMI and diluted with complete medium, afterwards. Lymphocytes cells were counted by hemocytometer (Neubaeur). The cells were then ready for testing and were cultured in $37^{\circ} \mathrm{C} \quad \mathrm{CO}_{2}$ incubator. Suspensions of lymphocytes cells in $100 \mu \mathrm{L}$ medium $\left(1.5 \times 10^{6}\right.$ cells $\mathrm{mL}^{-1}$ ) were distributed into 96-wells microplates (Nunc) wherein $10 \mu \mathrm{L}$ of hepatitis B vaccine Engerix $^{\circledR}$, GlaxoSmithKline) was added. Incubation was taken place at $37^{\circ} \mathrm{C}$ for $24 \mathrm{~h}$ in $5 \% \mathrm{CO}_{2}$ flow (Heraeus ${ }^{\circledR}$, Germany). Afterwards, $100 \mu \mathrm{L}$ of samples suspensions were added and incubation was continued for another 48h. Addition of $10 \mu \mathrm{L}$ of MTT $5 \mathrm{mg} / \mathrm{mL}$ [3-(4,5-dimethyl-thiazol-2-yl)2,5-diphenyltetra-zolium-bromide] (Merck, Germany) into each well was followed by $4 \mathrm{~h}$ of incubation at $37^{\circ} \mathrm{C}$. Viable cells will form purple color as a result of reaction with MTT reagent. Reagent stopper $(10 \%$ SDS $)$ in $50 \mu \mathrm{L}$ of $\mathrm{HCl} 0.01 \mathrm{~N}$ was added into each wells. Optical densities were determined by using microplate reader (Bio-Rad Benchmark, Japan) at 550nm. PHA $5 \mu \mathrm{g} / \mu \mathrm{L}(10 \mu \mathrm{L})$ was used as control (Phytohemagglutinin, Merck, Germany).

\section{Macrophage isolation and phagocytosis activity with latex beads (Spilsbury et al., 1995).}

Macrophages were isolated from mice peritoneal fluid with $\pm 10 \mathrm{~mL}$ of cold RPMI. Aliquot was centrifuged at $1,200 \mathrm{rpm} 4^{\circ} \mathrm{C}$ for $10 \mathrm{~min}$. About $3 \mathrm{~mL}$ of RPMI 1640 complete 
media (contains FBS 10\% (v/v) was added to sediment clumps. Cells were counted by hemocytometer (Neubaeur) and then resuspended in complete medium to obtain $1.38 \times 10^{6}$ cells $\mathrm{mL}^{-1}$ cell density. Afterwars, cell suspension was inoculated on microtiter plate 24wells (Nunc) which covered by round cover slips. Each well contains $200 \mu \mathrm{L}$ suspension $\left(2.8 \times 10^{5}\right.$ cells). Cells were incubated in $\mathrm{CO}_{2} 5 \%$ incubator at $37^{\circ} \mathrm{C}$ for $30 \mathrm{~min}$. Afterwards each well was washed with $250 \mu \mathrm{L}$ complete medium three times, followed by incubation for $2 \mathrm{~h}$. Cells were washed with RPMI 1640 twice and then $1 \mathrm{~mL}$ complete medium was added, followed by $24 \mathrm{~h}$ incubation.

Non specific phagocytic activity was performed in vitro by using $3 \mu \mathrm{m}$ latex beads (Leijh et al., 1986). Latex beads (Sigma-Aldrich, Germany) were resuspended in PBS to get concentration of $2.5 \times 10^{6}$ particles $\mathrm{mL}^{-1}$. After $24 \mathrm{~h}$ cultured, peritoneal macrophages were washed twice with RPMI 1640. Latex suspension $(200 \mu \mathrm{L} /$ wells $)$ and samples $(200 \mu \mathrm{L} /$ wells $)$ were added into each wells and incubated in incubator $\mathrm{CO}_{2} 5 \% 37^{\circ} \mathrm{C}$ for $60 \mathrm{~min}$. Cells were then washed with PBS three times to eliminate excess latex beads. After left to dry in room temperature, fixation with methanol was done for 30s. Afterwards, methanol was aspired and cover slips were left to dry, followed by $2 \%(\mathrm{v} / \mathrm{v})$ Giemsa staining (Merck, Germany) for 20min. After being washed with distilled water, supernatant were aspired and wells were left to dry. The amount of macrophages which phagocyted the latex beads and latex beads consumed by the macrophages were counted under inverted microscope (Olympus, Germany) to calculate the macrophage phagocytic index. Positive control used was $10 \mu \mathrm{L}$ LPS (Lipopolysaccharide, Merck, Germany) $1 \mu \mathrm{g} / \mu \mathrm{L}$.

\section{RESULTS AND DISCUSSION Polysaccharide-rich fraction Yield}

Yields of polysaccharides-rich fraction from method I, II and III were 4.44\%, 9.69\% and $0.03 \% \mathrm{w} / \mathrm{w}$, respectively, while method IVa and IVb yielded $0.78 \%$ and $2.32 \% \mathrm{w} / \mathrm{w}$ respectively. Result of loss on drying parameter were as follow : 14,25\% w/w (method I), 17.62
$\% \mathrm{w} / \mathrm{w}(\operatorname{method} \mathrm{II}), 13.24 \% \mathrm{w} / \mathrm{w}(\operatorname{method} \mathrm{III})$, $16.62 \% \mathrm{w} / \mathrm{w}$ (method IVa), and $13.24 \% \mathrm{w} / \mathrm{w}$ (method IVb). It is interesting to note that the yield from method I, was much lower than previously reported $(6.24 \% \mathrm{w} / \mathrm{w})$ (Nayak and Mengi, 2010). This might be due to the lower water content, since the fraction was freezedried rather than air-dried. Moreover, method III resulted the lowest yield. Previous report stated approx. $13 \% \mathrm{w} / \mathrm{w}$ polysaccharide-rich fraction was yielded from the fruit juice (Furusawa et al., 2003). Fraction yielded from method III exhibited the best appearance as white dried powder with less unpleasant odour characteristic to the fruit.

Result of quantitative analyses of total polysaccaride content by Phenol Sulfuric Acid method calculated as Dextran were 25.98\% w/w (method I), $28.50 \% \mathrm{w} / \mathrm{w}$ (method II), $25.98 \%$ w/w (method III), $13.79 \%$ w/w (method IVa), and 32.58\% w/w (method IVb), respectively. Different result was observed in method III, which reported that the fraction was almost entirely consisted of carbohydrates. Low level of purity of fraction yielded in our research may explain the situation due to less purification steps used in comparison to method used by Furusawa et al. (2003).

The result of total polysaccharide content suggests different quality of polysaccharide in each fractions which possibly due to different type of polysaccharide and/or coexisting of other substances in the fraction. Considering that tannin, peptide, and saponin glycoside are compounds from plant which are usually very polar and may also obtained with the isolation procedure used, further analyses were done based on those respective group of compounds (Table I).

Samples from method I, III and IVb contained N-bearing substances (Table I). It is worth noted that saponin and $\mathrm{N}$-containing substances were not found in the same fraction. Negative result in Biuret test suggests that the N-containing substances may be amino acids or alkaloids, but not peptides. Chromophore substances were detected in all fractions suggests substances having long conjugated bonds. Tannin might be the responsible substances, but unfortunately no phenolic substances detected in all samples. 
Table I. Identification of chemical group content in isolates from three different methods

\begin{tabular}{cccccccc}
\hline \multirow{2}{*}{ Method } & $\begin{array}{c}\text { Molisch } \\
\text { Tube Test }\end{array}$ & $\begin{array}{c}\text { Reducing } \\
\text { Sugar }\end{array}$ & $\begin{array}{c}\text { Protein } \\
\text { Tube test }\end{array}$ & $\begin{array}{c}\text { Chromo- } \\
\text { phores }\end{array}$ & Phenolics & Saponin & $\begin{array}{c}\text { N-containing } \\
\text { substances }\end{array}$ \\
\hline I & + & + & - & + & - & - & + \\
II & + & + & - & + & - & + & - \\
$\mathrm{III}$ & + & + & - & + & - & - & + \\
$\mathrm{IVa}$ & + & + & - & + & - & - & - \\
$\mathrm{IVb}$ & + & + & - & + & - & - & + \\
\hline
\end{tabular}

Table II. Result of Immunomodulatory activities if polysaccharide fraction of "Mengkudu"fruit

\begin{tabular}{lllllcc}
\hline \multirow{2}{*}{ Method } & \multicolumn{2}{c}{$\begin{array}{c}\text { Concentration }(\mu \mathrm{g} / \mathrm{mL}) \text { of fraction to have } \\
\text { stimulatory effect significantly different with control }\end{array}$} & \multicolumn{3}{c}{$\begin{array}{c}\text { Optimal Concentration } \\
(\boldsymbol{\mu} \mathbf{g} / \mathbf{m L})\end{array}$} \\
\cline { 2 - 7 } & PR & PI & L & PR & PI & $\mathbf{L}$ \\
\hline I & - & - & 100 & - & - & 100 \\
\hline II & 10 & - & 10,100 & 10 & - & 10 \\
\hline III & 10,50 & 10,50 & 50,100 & 50 & 10 & 100 \\
\hline IVa & $10,50,100$ & $10,50,100$ & 100 & 10 & 10 & 100 \\
\hline IVb & 10 & 50 & 100 & 10 & 50 & 100 \\
\hline
\end{tabular}

Note: PR = Phagocytic Ratio; PI: Phagocytic Index; L: Lymphocyte proliferation; $\mathrm{n}=3, \alpha<0,05$

Nevertheless, in order to eliminate a posiblity of false negative result of some substituted phenols detection using TLC- $\mathrm{FeCl}_{3}$ reagent, total phenolic content was determined by Folin Ciocalteau method.

Results of phenolics content assay were calculated as Gallic Acid Equivalent (GAE) as follows: $1.72 \% \mathrm{w} / \mathrm{w}$ (method I), $1.70 \% \mathrm{w} / \mathrm{w}$ (method II), 0.44\% w/w (method III), $0.98 \%$ $\mathrm{w} / \mathrm{w}(\operatorname{method} \mathrm{IVa})$, and $3.73 \% \mathrm{w} / \mathrm{w}(\operatorname{method}$ $\mathrm{IVb})$. The result of total phenolics assays were not solely determined by the amount of phenolic content in the fraction, but also influenced by other reducing substances, such as reducing sugar etc. The fact that fraction from method III showed also the lowest content of phenolics and no saponin detected suggests that alkaloids may be present in higher amount than in other fraction.

\section{Result of Immunostimulatory effects of yielded fractions}

Result of immunostimulatory assay of each fractions (Table II) showed that in accordance to the chemicals content, the activities were varied. Phagocytic ratio showed the macrophages amount in 100 macrophages which actively phagocyted latex, while phagocytic Index showed the number of latex which were phagocyted by 100 macrophages. According to Kouakou et al. (2013), a common feature of plant polysaccharides that modulate macrophage function may be higher molecular weight as were found previously from some researchs (Schepetkin et al., 2008; Xie et al., 2007; and Xie et al., 2008) that immunomodulatory activity positively correlated with increased molecular weight of various plant polysaccharides. It has been reported that polysaccharides are able to bind to phenolic substances by intermolecular interactions (Renard et al., 2001), which changing the molecular conformation of carbohydrates. From our research, it can be reported as well as their researchs. Fraction from method III has lowest content of phenolics which showed a highest macrophage activities while method I which has a highest content of phenolics showed a lowest macrophage activities.

Lymphocyte proliferation was determined by comparing the optical densities of samples to control. Fraction from method IVb showed a highest potency in lymphocyte proliferation stimulatory effect but method III has the lowest lymphocyte proliferation 


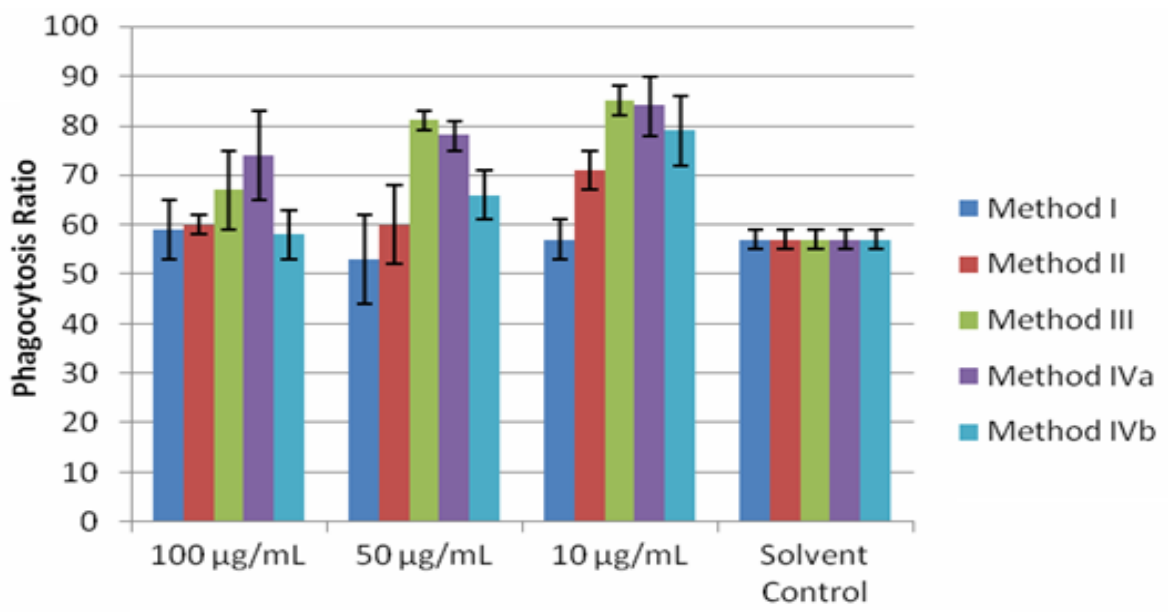

Figure 1. Phagocytosis ratio of the polysaccharide-rich fractions $(\mathrm{n}=3)$

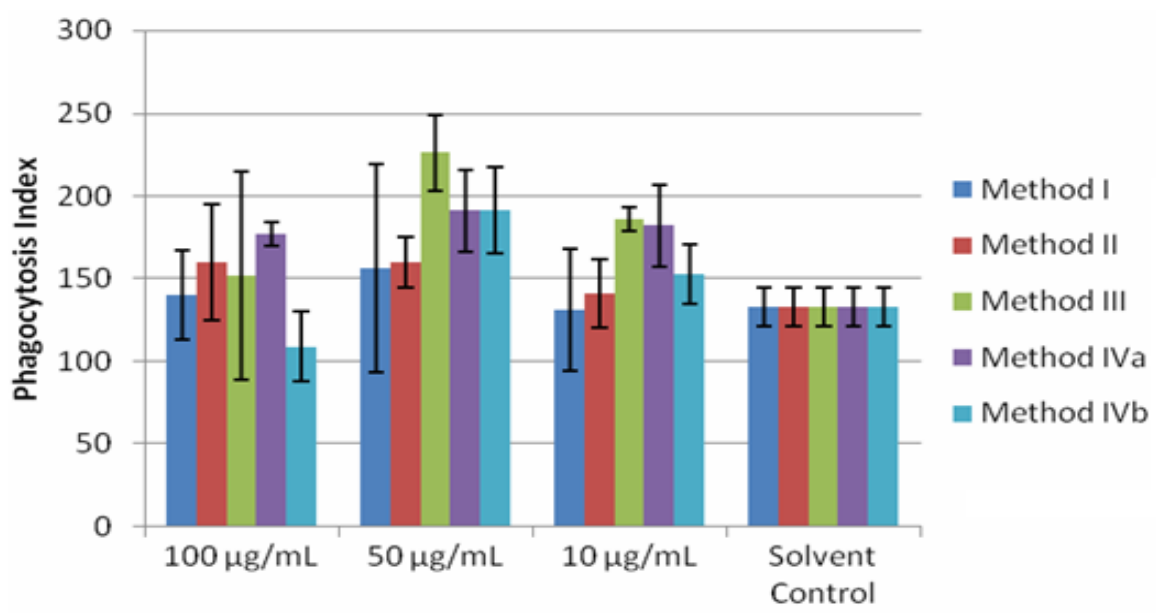

Figure 2. Phagocytic Index of the polysaccharide-rich fractions $(\mathrm{n}=3)$

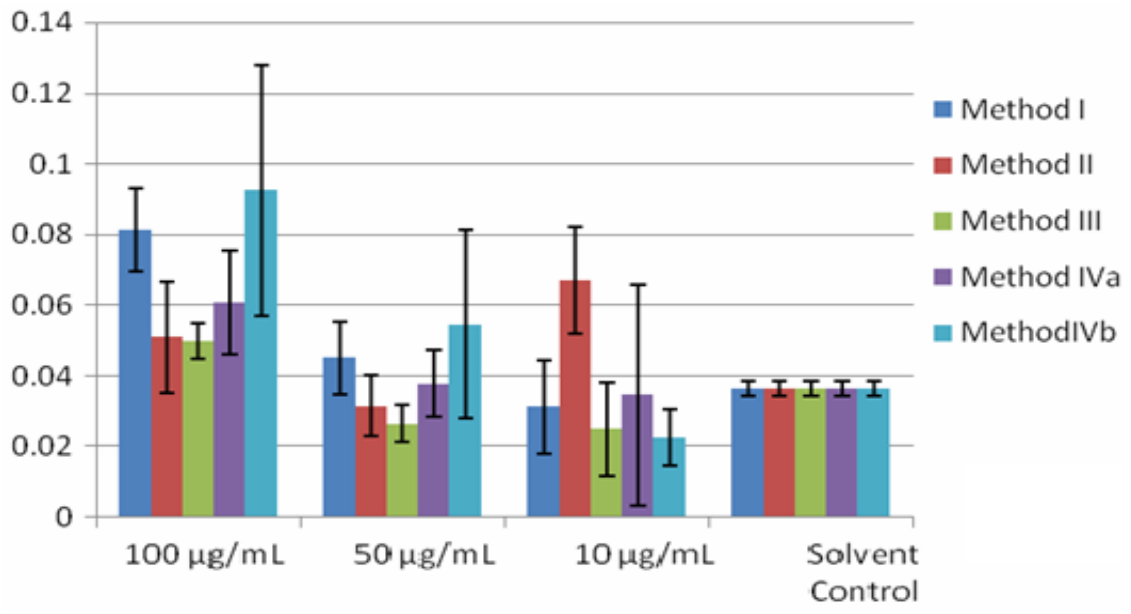

Figure 3. Optical density the lymphocyte cells suspension in the present of the polysaccharide-rich fractions $(n=3)$ 
stimulatory effect (Figure 1-3). In general, no concentration dependent activity observed for phagocytosis activity of the macrophages as well as in lymphocyte proliferation, except for method II.

\section{CONCLUSION}

It can be concluded, that different methods resulted in different yield, phytochemical characteristics and immuno stimulatory activities of polysaccharides-rich fractions. The phytochemical test on polysaccharide fractions from method I and III revealed the presence of alkaloid. On the other hand, method III and IV resulted fractions with the presence of glycosides. There were no protein and free-phenolic substances detected from all methods. The highest result of polysaccharide content was found from method IVb (32.58\%). Method III showed the highest activity on phagocytic activity of the macrophage, while method IVb caused the highest stimulation on lymphocyte proliferation.

\section{ACKNOWLEDGEMENT}

We wish to thank Mrs.Istini (UGM Research and Assessment Integrated Laboratory) and Mr. Djoko Santosa (Laboratory of Pharmacognosy, Faculty of Pharmacy UGM) for valuable technical assistance. Thank you to Faculty of Pharmacy UGM for supporting this research.

\section{REFERENCES}

AOAC (1990). Official Methods of Analysis, $15^{\text {th }}$ Ed., AOAC Inc., Virginia, pp.10201021.

Chen XT, Li Y, Wang HL, Cheng WM, Zhang L, Ge JF, 2006. Immunomodulating Effects of Fractioned Polysaccharides Isolated from Yu-Ping-Feng-Powder in Cyclophosphamide-Treated Mice. The American Journal of Chinese Medicine. 34(4): 631-641.

Chun OK, Kim DO, Lee CY, 2003. Superoxide Radical Scavenging Activity of the Major Polyphenols in Fresh Plum. J Agric Food Chem. 51: 8067-8072.

Ediati S, Mulyaningsih S, Untari KE, Widyaningrum, 2006. Immunostimulant activity of soybean milk against immunoglobulin (IgG, igA) and lymphocyte cells proliferation of balb/c mice induced hepatitis A. Indonesian J. Pharm. 17(3): 156-161.

Furusawa E, Hirazumi A, Story S, Jensen J, 2003. Antitumour Potential of a Polysaccharide-rich Substance from the Fruit Juice of Morinda citrifolia (Noni) on Sarcoma 180 Ascites Tumour in Mice. Phytother Res. 17: 1158-1164. DOI:10.1002/ptr.1307.

Guan D, Zhang Z, Yang Y, Xing G, Liu J, 2011. Immunomodulatory activity of polysaccharide from the roots of Actinidia kolomikta on macrophages. Int. J of Biol, 3(2):3-10

Hirazumi A, Furuzawa E, 1999. An immunomodulatory polysaccharide-rich substance from the fruit juice of Morinda citrifolia (noni) with antitumor activity. Phytother Res. 13(5): 380-7.

Kouakou K, Schepetkin IA, Jun SM, Kirpotina LN, Yapi A et al., 2013. Immunomodulatory activity of polysaccharides isolated from Alchornea cordifolia. I Ethnopharmacol.146(1): 232242.

Leijh PC, Van Furth R, Van Zwet TL, 1986. In vitro determination of phagocytosis and intracellular by polymorphonuclear and mononuclear phagocyte. In: M.D. Weir, L.A. Herzenberg and C. Blackwell editors. Handbook of experimental immunology, 4th edition, Wiley Blackwell Scientific Publications, Oxford:1-21.

Nayak S, Mengi S, 2010. Preliminary physicochemical and phytochemical evaluation of Morinda citrifolia fruit Extractives. Int J Pharm and Pharm Sci. 2(4):150-154

Renard CMGC, Baron A, Guyot S, Drilleau JF, 2001. Interaction between apple cell walls and native apple polyphenols: quantification and some consequences. Int J of Biol Macromol.29(2):115-125

Rohman A, Sumantri, 2007. Analisis Makanan. Universitas Gadjah Mada Press, Yogyakarta, pp.15, 44.

Sharma U, Bala M, Saini R, Verma PK, Kumar $\mathrm{N}$ et al., 2012. Polysaccharide enriched immunomodulatory fraction from 
Tinospora cardifolia (Willd) miers ax hook.F.\& Thoms. Indian J Exp Biol. Vol.50:612-617

Sjabana NA, Bahalwan, 2002. Khasiat dan Manfaat Mengkudu, cetakan I. Agromedia Pustaka, Jakarta, pp.2-7.

Spangenberg D, 2008. Derivatization, Detection (Quantification), and Identification of Compounds Online. In: Thin Layer Chromatography in Phytochemistry, CRC Press, Boca Raton:184-189.

Schepetkin IA, Xie G, Kirpotina LN, Klein RA, Jutila MA, Quinn M, 2008. Macrophage immunomodulatory activity of polysaccharides isolated from Opuntia polyacantha. Int Immunopharmacol. 8(10):1455- 1466

Spilsbury K, O'Mara M-A, Wu WM, Rowe PB, Symonds G, Takayama Y, 1995. Isolation of a Novel MacrophageSpecific Gene by Differential cDNA Analysis. Blood. 85(6):1620 -1629.

Wang MY, West BJ, Jensen CJ, Nowicki D, Chen S, Palu AK, Anderson G, 2002.
Morinda citrifolia (Noni): A literature review and recent advances in Noni research. Acta Pharmacologia Sinica. 23 (13): 1127-1141.

Wang PY, Zhu XL, Lin ZB, 2012, Antitumor and immunomodulatory effects of polysaccharides from broken-spore of Ganoderma lucidum. frontiers in Pharmacology, vol::3; Article 135

Xie G, Schepetkin IA, Quinn MT, 2007. Immunomodulatory activity of acidic polysaccharides isolated from Tanacetum vulgare. Int Immunopharmacol. 7(13):16391650

Xie G, Schepetkin IA, Siemsen DW, Kirpotina LN, Wiley IA, Quinn MT, 2008. Fractionatibiologically-active polysaccharides from Artemisia tripartite. Phytochemistry, 69(6): 1359-1371

Yin, Y, Fu, W, Fu, M, He, G, Traore L, 2007. The immune effect of edible fungus polysaccharides compounds in mice. Asia Pac J Clin Nutr, 16 (Suppl 1):258260. 